\title{
TOXINS OF PSEUDOMONAS PSEUDOMALLEI
}

\section{Characterization ${ }^{1}$}

\section{ROBERT J. HECKLY AND CLARA NIGG}

\author{
Naval Biological Laboratory, School of Public Health, University of California, Berkeley, California
}

Received for publication May 12, 1958

The presence of a lethal toxin in culture filtrates of Pseudomonas pseudomallei (Malleomyces pseudomallei) was reported by Nigg et al. in 1955. This crude toxin, which was thermolabile, was not only lethal for mice and hamsters but also produced hemorrhagic necrotic lesions on intradermal inoculation of normal guinea pigs. The filtrates have subsequently been shown to contain at least two thermolabile toxins, one which produced the necrotic lesion and the other which was nonnecrotizing but lethal for mice and hamsters. This report describes the effect of various treatments of the crude filtrates for the characterization, demonstration, and separation of these two toxins.

The crude culture filtrates also contained thermostable endotoxin which possessed properties common to the endotoxins of other gramnegative bacteria. Each filtrate was routinely checked for lethal endotoxin content by inoculating mice with boiled filtrate which, undiluted, usually killed 50 to 75 per cent of the test mice. No deaths occurred with a 1:2 dilution. Since the thermolabile toxin was lethal in considerably higher dilutions, the low endotoxin content did not interfere with the titration of the former. For purposes of brevity, the term "toxin," as used throughout this report, refers only to the thermolabile components and specifically to the lethal toxin unless designated otherwise.

\section{EXPERIMENTAL METHODS}

Production. The toxic culture filtrates were prepared with strain 111-9 of $P$. pseudomallei

1 This work was sponsored by the Office of Naval Research, U. S. Navy, under a contract between the Office of Naval Research and the Regents of the University of California.

Opinions expressed in this report are not to be construed as reflecting the view of the Navy Department or of the naval service at large (Article 1252, U. S. Navy Regulations, 1948). Reproduction in whole or in part is permitted for any purpose of the United States Government. as described by Colling et al. (1958). The cultures were grown statically at $32 \mathrm{C}$ for 7 to 12 days in either 4 per cent glycerin beef extract broth (glycerin broth) or 4 per cent glycerin beef heart infusion broth.

Assays for toxicity. Lethality; expressed as lethal units per $\mathrm{ml}(\mathrm{LU} / \mathrm{ml})$, was assayed as previously described (Colling et al., 1958).

Necrotoxin was assayed in normal adult albino guinea pigs by intradermal inoculation of $0.1 \mathrm{ml}$ of 2 -fold dilutions. One unit of necrotoxin is defined as the minimal amount which elicits a necrotic lesion.

Dialysis. The preparations were dialyzed at $4 \mathrm{C}$ for 3 to 5 days against at least 10 volumes of dialyzate, changed daily. Small volumes were agitated occasionally each day. For volumes larger than $15 \mathrm{ml}$ or for the removal of large amounts of salt, the dialyzing bag was rotated at approximately $200 \mathrm{rpm}$.

Lyophilization. For lyophilization, preparations were shell frozen at $-78 \mathrm{C}$ and dried for $24 \mathrm{hr}$ at 20 to $30 \mathrm{C}$ under 5 to $30 \mu \mathrm{Hg}$ pressure, using the apparatus described by Heckly et al. (1958).

Ammonium sulfate fractionation. Solid ammonium sulfate was added slowly with continuous mixing to crude filtrates to which sodium phosphate buffer at $\mathrm{pH} 7.0$ had been added to a final concentration of $0.01 \mathrm{M}$. The $\mathrm{pH}$ was adjusted and maintained by adding $5 \mathrm{M} \mathrm{NaOH}$ or $\mathrm{HCl}$ after each addition of ammonium sulfate. The concentration of ammonium sulfate is expressd as a weight/volume percentage in the final solution. The precipitates which formed at $4 \mathrm{C}$ during a period of at least $2 \mathrm{hr}$ were collected by centrifugation and washed with small volumes of ammonium sulfate solution of the same concentration as in the supernatants. The precipitates were dissolved in a minimal volume of distilled water or buffer and dialyzed free of sulfate ions. 


\section{RESULTS}

Properties of crude culture filtrates. (1) Effect of temperature:-A preliminary report (Nigg et al., 1955) showed that crude filtrates were both lethal and necrotizing. Table 1 shows that heating for $30 \mathrm{~min}$ at $50 \mathrm{C}$ had little effect on lethality, whereas heating for $30 \mathrm{~min}$ at $60 \mathrm{C}$ reduced the lethality by about 50 per cent and boiling for 15 min inactivated the toxin. The occasional death produced by boiled filtrate was attributed to endotoxin. Figure 1 shows that necrotoxicity was similarly affected by heating. Repeated freezing at $-78 \mathrm{C}$ and thawing at room temperature did not reduce the activity of either toxin. The lethal toxin was also very stable at $4 \mathrm{C}$;
TABLE 1

Effect of heating on lethality of crude filtrate $\$$

\begin{tabular}{|c|c|c|c|c|c|c|}
\hline \multirow{3}{*}{ Heating* } & \multicolumn{5}{|c|}{$\begin{array}{l}\text { Toxicity for Mice } \\
\text { (Dead/Total) }\end{array}$} & \multirow{3}{*}{$L U / m$} \\
\hline & \multicolumn{5}{|c|}{ Dilution: } & \\
\hline & None & 1:2 & 1:4 & $1: 8$ & 1:16 & \\
\hline None (control) & - & - & $8 / 8$ & $2 / 8$ & $0 / 8$ & 6.4 \\
\hline $50 \mathrm{C}, 30 \mathrm{~min}$. & - & - & $8 / 8$ & $1 / 8$ & $0 / 8$ & 6.0 \\
\hline $60 \mathrm{C}, 30 \mathrm{~min} \ldots$ & - & $8 / 8$ & $2 / 8$ & $0 / 8$ & $0 / 8$ & 3.2 \\
\hline Boiled $15 \min .$. & $1 / 8$ & - & - & - & - & $<1$ \\
\hline
\end{tabular}

* Twenty $\mathrm{ml}$ bottles were filled with culture filtrate 3 , sealed with rubber stoppers and submerged in water at the temperature indicated.

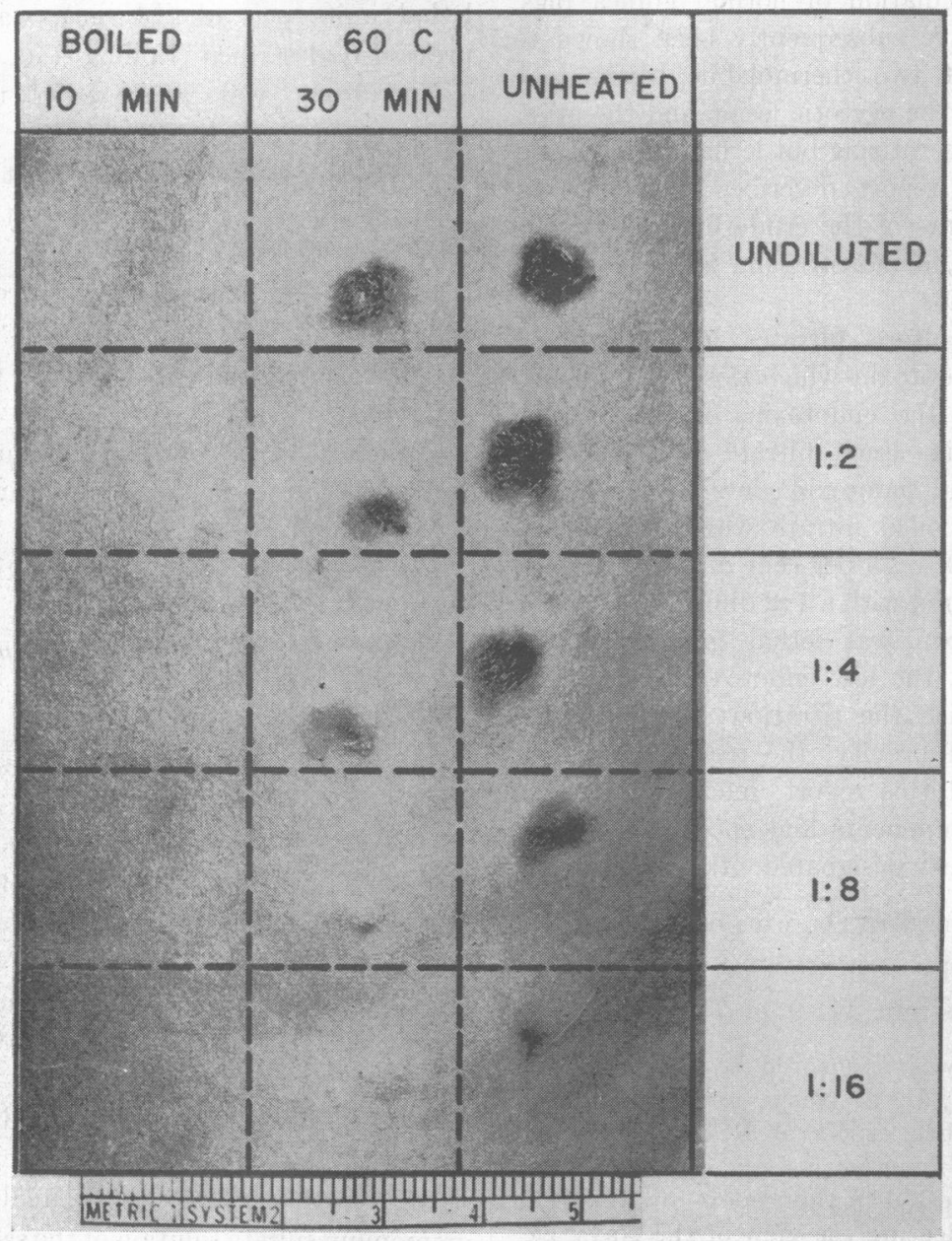

Figure 1. The effect of heat on the necrotizing action of filtrate 3 . The guinea pig was photographed 4 hr after inoculation. 
a crude filtrate was stored for more than 30 months with no loss of activity.

(2) $\mathrm{pH}$ stability:-At room temperature, toxin was rapidly inactivated below $\mathrm{pH} 6$ and above $\mathrm{pH} 9$, whereas little if any toxicity was lost in 13 days at $\mathrm{pH} 8$ (table 2). The effect of $\mathrm{pH}$ at other temperatures.has not been determined precisely but it has been observed that acid solutions of toxin were more stable at $4 \mathrm{C}$ than at room temperature.

(3) Effect of dialysis and lyophilization:-The results summarized in table 3 show that both the lethal and necrotizing toxicity of culture filtrates were reduced by approximately one-half on dialysis against distilled water or saline solution. Since both properties remained essentially undiminished on dialysis against glycerin broth, peptone solution, or phosphate buffer, the losses observed on dialysis against distilled water or saline solution were probably due to inactivation and not to passage through the membrane.

Table 3 also shows that in general those preparations which had lost lethal and necrotizing toxicity during dialysis retained their full reduced toxicity on subsequent lyophilization, whereas considerable loss was sustained on lyophilization of those preparations which contained glycerin. Dialysis against phosphate buffer or peptone solution minimized the loss of both lethal and necrotizing toxicity on lyophilization (table 3).

TABLE 2

Effect of $p H$ on lethality of crude filtrate 10 at room temperature

\begin{tabular}{|c|c|c|c|c|}
\hline \multirow{2}{*}{$\mathrm{pH}^{*}$} & \multicolumn{4}{|c|}{ Toxicity $(\mathrm{LU} / \mathrm{ml})$ after: } \\
\hline & $24 \mathrm{hr}$ & $48 \mathrm{hr}$ & 6 days & 13 days \\
\hline 3.0 & $<1.6$ & $<0.8$ & - & - \\
\hline 4.0 & - & $<0.8$ & - & - \\
\hline 5.0 & 2.5 & - & 1.4 & - \\
\hline 6.0 & - & 5.7 & 5.0 & - \\
\hline 6.8 & $>5.7$ & $>5.7$ & 5.7 & - \\
\hline 8.0 & $>5.7$ & $>5.7$ & 11.3 & 11.3 \\
\hline 9.0 & 5.0 & $>5.7$ & $>5.7$ & 6.4 \\
\hline 10.0 & $>5.7$ & 3.2 & 2.8 & - \\
\hline 11.0 & 2.5 & $>2.8$ & 2.8 & 2.8 \\
\hline $\begin{array}{c}\text { Control, at } 4 \\
\text { C, pH } 6.8 \ldots\end{array}$ & 10.1 & 一 & 11.3 & 8.0 \\
\hline
\end{tabular}

* Solutions were preserved with toluene and $\mathrm{pH}$ was adjusted with either $\mathrm{HCl}$ or $\mathrm{NaOH}$ after adding sodium phosphate to $0.05 \mathrm{~m}$.
TABLE 3

Effect of dialysis and lyophilization on toxicity of crude filtrate 3

\begin{tabular}{|c|c|c|c|c|}
\hline \multirow{3}{*}{ Dialyzate $^{*}$} & \multicolumn{4}{|c|}{ Toxicity } \\
\hline & \multicolumn{2}{|c|}{ After dialysis } & \multicolumn{2}{|c|}{$\begin{array}{l}\text { After dialysis } \\
\text { and lyophiliza- } \\
\text { tion }\end{array}$} \\
\hline & $\mathrm{LU} / \mathrm{ml}$ & $\left|\begin{array}{c}\text { Necro- } \\
\text { loxin } \\
\text { umits } / m l\end{array}\right|$ & $\mathrm{LU} / \mathrm{ml}$ & $\mid \begin{array}{l}\text { Necro- } \\
\text { loxin } \\
\text { units } / \text { ml }\end{array}$ \\
\hline Distilled water. & 4.0 & 40 & 5.0 & 40 \\
\hline $0.85 \% \mathrm{NaCl}$ solution. & 5.7 & 40 & 5.7 & 30 \\
\hline $\begin{array}{c}0.1 \text { м Phosphate buffer } \\
\text { pH } 7.0 \ldots \ldots \ldots\end{array}$ & 10.0 & 80 & 6.4 & 60 \\
\hline $\begin{array}{c}0.1 \text { м Borate buffer, } \\
\text { pH } 9.2 \ldots\end{array}$ & 8.0 & 60 & 5.7 & 30 \\
\hline $1 \%$ Peptone solution. & 11.3 & 80 & 6.4 & 80 \\
\hline \multirow[t]{2}{*}{ Glycerin broth....... } & 10.1 & 80 & 1.6 & 20 \\
\hline & \multicolumn{2}{|c|}{ Nondiaizyed } & \multicolumn{2}{|c|}{ Lyophilized } \\
\hline $\begin{array}{c}\text { Control: } \\
\text { broth culture fil- } \\
\text { trate } \ldots \ldots \ldots \ldots \ldots \ldots\end{array}$ & 10.1 & 80 & 4.0 & 40 \\
\hline
\end{tabular}

* Distilled water and saline solution adjusted to pH 7.2 to 7.5 with $\mathrm{NaOH}$ before dialysis. Fifteen ml of filtrate were dialyzed against 3 successive $200 \mathrm{ml}$ volumes of dialyzate for a total of 3 days. Toluene, as a preservative, was added to a final concentration of 0.5 per cent.

Storage at room temperature of these lyophilized preparations resulted in no additional loss of toxicity.

(4) Effect of ultrafiltration:-Table 4 shows that the toxin could be concentrated by ultrafiltration using the apparatus described by Heckly and Watson (1951). Traces were demonstrable in the first filtrate but most of the toxin was retained on subsequent filtration through a second membrane. Although the ultrafilter membrane did not allow the passage of serum albumin, its average pore size was slightly larger than that of the dialysis tubing, as indicated by the flow rate of water through both. Since the pore size was probably not absolutely uniform the most acceptable interpretation of the results is that the toxin was of a uniform but rather small molecular size.

(5) Effect of formaldehyde:-Detoxification of culture filtrate by 0.3 per cent formaldehyde is shown in table 5. Since the toxin, in the absence of formaldehyde, was denatured below $\mathrm{pH} 7$ and 
TABLE 4

Concentration by successive ultrafiltration

\begin{tabular}{|c|c|c|}
\hline Preparation & Volume & $\mathrm{LU} / \mathrm{ml}$ \\
\hline $\begin{array}{l}\text { Crude filtrate } 15 \ldots \ldots \ldots \ldots \ldots \\
\text { First concentrate } \ldots \ldots \ldots \ldots \ldots \\
\text { First filtrate } \ldots \ldots \ldots \ldots \ldots \ldots\end{array}$ & $\begin{array}{r}\mathrm{ml} \\
2000 \\
200 \\
1800\end{array}$ & $\begin{array}{l}5.7 \\
28 \\
0.7\end{array}$ \\
\hline $\begin{array}{l}\text { Second concentrate (Obtained } \\
\text { by refiltration of first filtrate) }\end{array}$ & 50 & 25 \\
\hline Second filtrate... & 1650 & $<0.4$ \\
\hline
\end{tabular}

of various organic solvents which might be useful in the fractionation or purification of toxic filtrates is shown in table 6. Apparently both lethal and necrotizing toxins were relatively stable in the alcohols and acetone, even at room temperature. On dialysis against 95 per cent ethanol, some precipitate appeared but it dissolved readily on dialysis against buffer. No precipitate was formed by 50 to 80 per cent ethanol.

The addition of phenol to a concentration of 5 per cent produced a distinct turbidity, however there was no sediment after centrifugation for

TABLE 5

Effect of $p H$ on detoxification of crude filtrate 10 by 0.3 per cent formaldehyde

\begin{tabular}{|c|c|c|c|c|c|c|c|c|c|}
\hline \multirow{4}{*}{ Preparation } & \multicolumn{3}{|c|}{ Incubation } & \multicolumn{6}{|c|}{ Toxicity in Mice (Dead/Total) } \\
\hline & \multirow{3}{*}{ Temp } & \multirow{3}{*}{$\underset{\mathrm{pH}}{\text { Initial }}$} & \multirow{3}{*}{$\underset{\mathrm{pH}}{\text { Final }}$} & \multicolumn{3}{|c|}{$\begin{array}{c}\text { After } 7 \text { days' } \\
\text { incubation }\end{array}$} & \multicolumn{3}{|c|}{$\begin{array}{c}\text { After } 14 \text { days' } \\
\text { incubation }\end{array}$} \\
\hline & & & & \multicolumn{6}{|c|}{ Dilution } \\
\hline & & & & None & $1: 2$ & $1: 4$ & None & $1: 2$ & $1: 4$ \\
\hline $\begin{array}{l}\text { Filtrate with formal- } \\
\text { dehyde }\end{array}$ & $37 \mathrm{C}$ & $\begin{array}{l}5.0 \\
6.0 \\
7.0 \\
8.0 \\
9.0\end{array}$ & $\begin{array}{l}4.5 \\
- \\
5.4 \\
6.6 \\
7.7\end{array}$ & $\begin{array}{l}- \\
- \\
-\end{array}$ & $\begin{array}{l}0 / 4 \\
0 / 4 \\
0 / 4 \\
0 / 4 \\
0 / 4\end{array}$ & $\begin{array}{l}0 / 4 \\
0 / 4 \\
0 / 4 \\
0 / 4 \\
0 / 4\end{array}$ & $\begin{array}{l}2 / 4 \\
2 / 4 \\
3 / 4 \\
4 / 4 \\
1 / 4\end{array}$ & $\begin{array}{l}0 / 4 \\
0 / 4 \\
0 / 4 \\
0 / 4 \\
0 / 4\end{array}$ & $\begin{array}{l}- \\
- \\
- \\
-\end{array}$ \\
\hline $\begin{array}{l}\text { Filtrate without for- } \\
\text { maldehyde }\end{array}$ & $37 \mathrm{C}$ & $\begin{array}{l}5.0 \\
6.0 \\
7.0 \\
8.0 \\
9.0\end{array}$ & $\begin{array}{l}5.0 \\
5.5 \\
6.0 \\
7.3 \\
8.2\end{array}$ & $\begin{array}{l}- \\
- \\
- \\
-\end{array}$ & $\begin{array}{l}0 / 4 \\
4 / 4 \\
4 / 4 \\
3 / 4 \\
1 / 4\end{array}$ & $\begin{array}{l}0 / 4 \\
0 / 4 \\
3 / 4 \\
0 / 4 \\
0 / 4\end{array}$ & $\begin{array}{l}3 / 4 \\
3 / 4 \\
4 / 4 \\
4 / 4\end{array}$ & $\begin{array}{l}0 / 4 \\
0 / 4 \\
4 / 4 \\
4 / 4 \\
1 / 4\end{array}$ & $\begin{array}{l}- \\
\overline{1 / 4} \\
- \\
-\end{array}$ \\
\hline $\begin{array}{l}\text { Filtrate without for- } \\
\text { maldehyde }\end{array}$ & $4 \mathrm{C}$ & 6.3 & 6.3 & - & $4 / 4$ & $4 / 4$ & - & $4 / 4$ & $4 / 4$ \\
\hline
\end{tabular}

above $\mathrm{pH} 8$, it should be buffered at about $\mathrm{pH} 7$ during conversion of toxin to toxoid with formaldehyde. Residual toxicity was probably due to endotoxin which was resistant to formaldehyde.

(6) Immunogenicity:-Repeated inoculation of sublethal doses of crude toxin or toxoid increased the resistance of mice to toxin. Mice inoculated with 3 sublethal doses of crude toxin at weekly intervals survived a challenge with crude toxin of 2 to 4 times the amount which killed control mice. Mice inoculated with one dose of $0.5 \mathrm{ml}$ plus 2 doses of $1 \mathrm{ml}$ each of crude toxoid showed an immunity index of 15 to 18 when challenged with ammonium sulfate precipitated toxin.

(7) Effect of organic reagents:-The effect
30 min at $2000 \times$ G. At least 50 per cent of both the lethal and necrotizing toxins was inactivated by 5 per cent phenol (table 7). In view of these results, phenol did not seem to be suitable for fractionation.

Fractionation. (1) Ammonium sulfate fractionation:-Table 8 shows that $\mathrm{pH} 7.0$ was nearly optimal for the fractionation of crude filtrate with increasing concentrations of ammonium sulfate. The fraction precipitated at each $\mathrm{pH}$ by 20 per cent ammonium sulfate was largely inactive and solutions of those fractions were extremely viscous and opalescent. Solutions of the other fractions were fluid and clear. Most of the toxin was precipitated by 30 per cent ammonium sulfate 
TABLE 6

Effect of organic solvents on crude filtrate 51

\begin{tabular}{|c|c|c|c|c|}
\hline \multirow[b]{2}{*}{ Solvent } & \multirow[b]{2}{*}{ Method of Adding Solvent } & \multirow[b]{2}{*}{$\begin{array}{c}\text { Final } \\
\text { Solvent } \\
\text { Conc }\end{array}$} & \multicolumn{2}{|c|}{$\begin{array}{l}\text { Toxicity } \\
\text { Retained }\end{array}$} \\
\hline & & & 营 & 苞 \\
\hline \multirow{5}{*}{ Ethanol } & & $\%$ & $\%$ & $\%$ \\
\hline & $\begin{array}{l}95 \% \text { alcohol mixed } \\
\text { with filtrate at } \\
20 \mathrm{C}\end{array}$ & 50 & 85 & - \\
\hline & $\begin{array}{c}\text { Dialyzed vs. } 50 \% \\
\text { alcohol } \dagger \text { at } 4 \mathrm{C}\end{array}$ & & 100 & 100 \\
\hline & $\begin{array}{c}\text { Dialyzed vs. } 80 \% \\
\text { alcohol } \dagger \text { at } 4 \mathrm{C}\end{array}$ & 80 & 100 & 100 \\
\hline & $\begin{array}{c}\text { Dialyzed vs. } 95 \% \\
\text { alcohol at } 4 \mathrm{C}\end{array}$ & 95 & 48 & - \\
\hline \multirow[t]{2}{*}{$\begin{array}{l}\text { Isopropyl } \\
\text { alcohol }\end{array}$} & $\begin{array}{l}90 \% \text { alcohol mixed } \\
\text { with filtrate at } \\
20 \mathrm{C}\end{array}$ & 50 & 94 & - \\
\hline & $\begin{array}{c}\text { Dialyzed vs. } 50 \% \\
\text { alcohol } \dagger \text { at } 4 \mathrm{C}\end{array}$ & 50 & 72 & - \\
\hline \multirow[t]{2}{*}{ Acetone } & $\begin{array}{l}\text { Acetone mixed } \\
\text { with filtrate at } \\
20 \mathrm{C}\end{array}$ & 50 & 81 & - \\
\hline & $\begin{array}{c}\text { Dialyzed vs. } 50 \% \\
\text { acetone } \dagger \text { at } 4 \mathrm{C}\end{array}$ & 50 & 70 & 50 \\
\hline $\begin{array}{l}\text { None (con- } \\
\text { trol) }\end{array}$ & $\begin{array}{l}\text { Dialyzed } v s \text {. phos- } \\
\text { phate buffer }\end{array}$ & - & 100 & 100 \\
\hline
\end{tabular}

* Solvent was removed by dialysis against 0.05 м phosphate buffer at $\mathrm{pH} 7.0$ to 7.5. Toxicity is expressed as the percentage of original toxicity of the aliquot.

† Solvent diluted with $0.05 \mathrm{~m}$ phosphate buffer, pH 7.0 to 7.5 .

regardless of $\mathrm{pH}$. A comparison of tables 8 and 9 shows that at pH 7.0 practically all of the toxin could be precipitated in fraction II by increasing the ammonium sulfate concentration from 30 to 35 per cent. On a dry weight basis, fraction II was approximately 3 times as active as either of the other two fractions (table 9). However, as will be shown in the section on electrophoretic separation, at least three-fourths of fraction II consisted of inactive substances.

(2) Dialysis and lyophilization:-Although there was a significant loss of toxicity when crude filtrates were dialyzed against saline solution or distilled water, table 10 shows that ammonium
TABLE 7

Effect of phenol on toxicity of crude filtrates

\begin{tabular}{c|c|c|c}
\hline \multirow{2}{*}{ Filtrate } & \multirow{2}{*}{ Phenol* Conc } & \multicolumn{2}{|c}{ Toxicity after Treatment } \\
\cline { 2 - 4 } & & LU/ml & $\begin{array}{c}\text { Necrotoxin } \\
\text { units/ml }\end{array}$ \\
\hline \multirow{3}{*}{3} & None & 6.4 & 80 \\
& 1 & 5.7 & 40 \\
& 5 & 3.2 & 20 \\
\hline 8-P & None & 11.3 & 100 \\
& 5 & 5.7 & 40 \\
\hline
\end{tabular}

* Phenol was dissolved in the filtrate at room temperature to give the concentration indicated. The phenolized preparation was incubated at $37 \mathrm{C}$ for $1 \mathrm{hr}$, then dialyzed 5 days $v s$. glycerin broth at $4 \mathrm{C}$.

TABLE 8

Effect of $p H$ on the precipitation of toxin by ammonium sulfate*

\begin{tabular}{c|c|c|c|c}
\hline & & \multirow{2}{*}{$\begin{array}{c}\text { Ammon- } \\
\text { Fum } \\
\text { sulfate }\end{array}$} & \multicolumn{2}{|c}{ Toxicity } \\
\cline { 3 - 4 } & & $\mathrm{pH}$ & $\mathrm{LU} / \mathrm{ml}$ & $\begin{array}{c}\text { LU/ } \\
\text { fraction }\end{array}$ \\
\hline I & 6.0 & 20 & 1.4 & 28 \\
II & & 30 & 14.0 & 280 \\
III & & 40 & 14.0 & 280 \\
\hline I & 7.0 & 20 & 4.0 & 80 \\
II & & 30 & 28.0 & 560 \\
III & & 40 & 5.7 & 114 \\
\hline I & 8.0 & 20 & 1.4 & 28 \\
II & & 30 & 13.0 & 260 \\
III & & 40 & 5.7 & 114 \\
\hline Crude filtrate & - & - & 4.0 & - \\
\hline
\end{tabular}

* Consecutive precipitation from $200 \mathrm{ml}$ crude filtrate 10 at each $\mathrm{pH}$, which was adjusted with $5 \mathrm{~N} \mathrm{HCl}$ or $\mathrm{NaOH}$ at each addition of ammonium sulfate. Precipitates were dissolved in $15 \mathrm{ml}$ of glycerin broth, dialyzed for a total of 5 days against 3 volumes of $150 \mathrm{ml}$ of glycerin broth. The volume was adjusted to $20 \mathrm{ml}$ before testing.

sulfate precipitated toxin lost little or no activity during dialysis against distilled water. Table 10 also shows that the ammonium sulfate precipitated toxin that had been dialyzed against distilled water lost little activity on subsequent lyophilization and reconstitution. However, as 
TABLE 9

Toxicity and dry weight of fractions successively precipitated at $p H 7.0$ from filtrate 11 by ammonium sulfate

\begin{tabular}{r|r|r|r|r}
\hline Fraction & $\begin{array}{c}\text { Ammonium } \\
\text { Sulfate }\end{array}$ & $\begin{array}{c}\text { Total Solids } \\
\text { per Fraction }\end{array}$ & \multicolumn{2}{|c}{ Toxicity } \\
\cline { 5 - 6 } & & \multicolumn{1}{c}{ LU/mg } & LU/fraction \\
\hline & $\%$ & $m g$ & & \\
I & 20 & 140 & 1.2 & 140 \\
II & 35 & 430 & 3.1 & 1340 \\
III & 45 & 64 & $<1.2$ & $<77$ \\
\hline
\end{tabular}

TABLE 10

Effect of dialysis and lyophilization on toxicity of fractions successively precipitated from filtrate 10 by ammonium sulfate

\begin{tabular}{|c|c|c|c|c|}
\hline \multirow[b]{2}{*}{$\begin{array}{l}\text { Frac- } \\
\text { tion }\end{array}$} & \multirow[b]{2}{*}{$\begin{array}{c}\text { Am- } \\
\text { monium } \\
\text { Sulfate }\end{array}$} & \multirow[b]{2}{*}{ Dialyzate* } & \multicolumn{2}{|c|}{$\begin{array}{l}\text { Toxicity } \\
\text { (LU } \mathbf{U} / \mathbf{m l})\end{array}$} \\
\hline & & & $\begin{array}{c}\text { After } \\
\text { dialysis }\end{array}$ & \begin{tabular}{|l} 
After \\
dialysis \\
and \\
lophi- \\
lizationt
\end{tabular} \\
\hline I & $\begin{array}{l}\% \\
20\end{array}$ & $\begin{array}{l}\text { Distilled water } \\
\text { Glycerin broth }\end{array}$ & $\begin{array}{l}1.8 \\
2.0\end{array}$ & $\begin{array}{l}1.0 \\
1.0\end{array}$ \\
\hline II & 35 & $\begin{array}{l}\text { Distilled water } \\
\text { Glycerin broth }\end{array}$ & $\begin{array}{l}56 \\
67\end{array}$ & $\begin{array}{l}40 \\
7.1\end{array}$ \\
\hline III & 45 & $\begin{array}{l}\text { Distilled water } \\
\text { Glycerin broth }\end{array}$ & $\begin{array}{l}4.0 \\
5.7\end{array}$ & $\begin{array}{l}3.2 \\
1.6\end{array}$ \\
\hline
\end{tabular}

* Aliquots of the precipitates were dissolved in and dialyzed against either distilled water or glycerin broth for at least 5 days against 3 changes of $200 \mathrm{ml}$ dialyzate.

$\dagger$ Reconstituted to prelyophilization volume, 40 $\mathrm{ml}$, with distilled water.

with the crude toxin (table 3), lyophilization markedly reduced the toxicity of the aliquots previously dialyzed against glycerin broth, particularly that of fraction II.

(3) Ultracentrifugation:-A model L Spinco ultracentrifuge was used with a number 40 rotor which accepts $12 \mathrm{ml}$ plastic tubes. Centrifugation of an ammonium sulfate precipitated toxin for an hour at $40,000 \mathrm{rpm}$ (a mean force of $105,400 \times$ G) resulted in an appreciable amount of sediment as a translucent, brownish pellet. This pellet, when diluted to the original volume, was not toxic, whereas the supernatant retained full toxicity. Since the toxin was not sedimented under conditions which would have removed serum globulin, it is probable that the molecular weight of the toxin was less than 100,000 , which is in agreement with the results of the ultrafiltration experiments (table 4).

(4) Electrophoresis:-The standard 3 by 25 by $80 \mathrm{~mm}$ Tiselius cell was used with an Aminco electrophoresis apparatus. After the electrophoretic separation, 0.25 to $0.5 \mathrm{ml}$ samples were withdrawn from the desired level in the cell with a syringe and long 18 gauge stainless steel cannula as described by Heckly (1954). Electrophoresis of 35 per cent ammonium sulfate precipitated toxin showed that the mobility of the toxic component was between +0.4 and $-0.5 \times 10^{-5}$ $\mathrm{cm}^{2} / \mathrm{sec} / \mathrm{v}$. The Schlieren pattern (figure 2) showed a major nontoxic component with a mobility of $-5.3 \times 10^{-5} \mathrm{~cm}^{2} / \mathrm{sec} / \mathrm{v}$. There was another component with a mobility of approximately $-0.5 \times 10^{-5} \mathrm{~cm}^{2} / \mathrm{sec} / \mathrm{v}$ but the sampling techniques were not sufficiently precise to determine the toxicity of this component specifically. On the basis of the electrophoretic results one can deduce that the toxin represented less than onethird of the total substance, since the leading component which was free of toxin represented at least one-half of the total area of the pattern; and the delta or epsilon boundary should account for at least one-half of the remaining area. The patterns and toxicity of samples in the presence of borate buffer at pH 9.3 or phosphate buffer at $\mathrm{pH} 7.5$ were comparable to those described above. These results indicate that considerable purification might be obtained by electrophoretic separation.

(5) Adsorption:-Because direct precipitation did not seem to be entirely satisfactory for initial purification, an attempt was made to adsorb the toxin selectively with various synthetic ionic and nonionic resins, charcoal, and other materials. Toxin was removed from solution by several of these adsorbents but could not be eluted from most of them, either because the toxin was too firmly adsorbed or because it had been inactivated. The majority of the substances tested adsorbed no toxin under the test conditions.

Charcoal effectively removed toxin from solution. As little as $1.6 \mathrm{~g}$ removed practically all of the toxin from $100 \mathrm{ml}$ of filtrate containing 8 $\mathrm{LU} / \mathrm{ml}$, but no toxin was eluted by any of the means tried. Inoculation of dilutions of the 

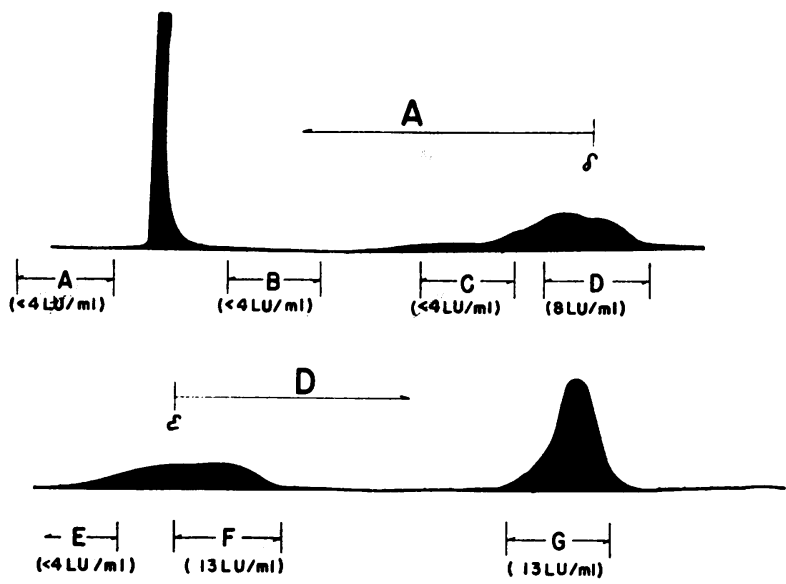

Figure 2. Electrophoretic pattern of toxin precipitated by 35 per cent ammonium sulfate, fraction II, in $0.1 \mathrm{~m}$ acetate buffer, $\mathrm{pH}$ 6.5. Patterns were obtained after $243 \mathrm{~min}$ at $4.7 \mathrm{v} / \mathrm{cm}$. Areas from which samples were removed are indicated below each pattern with the approximate toxicity.

washed charcoal demonstrated that the toxin was not destroyed.

The affinity of resins for toxin did not seem to be correlated with either their anionic or cationic properties. Of those tested, Duolite $\mathrm{S}-30^{2}$ seemed to be the most promising. Figure 3 shows that the adsorption of lethal toxin was inversely proportional to the $\mathrm{pH}$ from $\mathrm{pH} 6$ to 8 . Toxin was most effectively adsorbed from acid solutions but since the toxin had been shown to be relatively unstable below $\mathrm{pH} 6$ (table 2) filtrates were adjusted to about $\mathrm{pH} 6.5$ for adsorption of toxin.

The results of a typical operation cycle of a column of Duolite S-30 are graphically presented in figure 4. The bed volume was $5 \mathrm{ml}$ and the flow rate was regulated electrolytically (Heckly, 1958) to yield $4 \mathrm{ml}$ fractions which were automatically collected at 20 -min intervals. No toxin was demonstrable in the first 50 effluent fractions, but as additional toxin was added, the toxicity of the effluent fractions rapidly increased to about two-thirds of the influent toxicity. The column was washed with $\mathrm{pH} 7.0$ phosphate buffer without appreciable elution of either protein or toxin, but lethal toxin was effectively eluted by $\mathrm{pH} 10$ buffer. Although, on the basis of optical density, considerable purification was effected by adsorption on the column and subsequent elution, the

2 Duolite S-30, a synthetic nonionic resin, designed for decolorizing sugar solutions, was obtained from the Chemical Process Company, 901 Spring St., Redwood City, California.

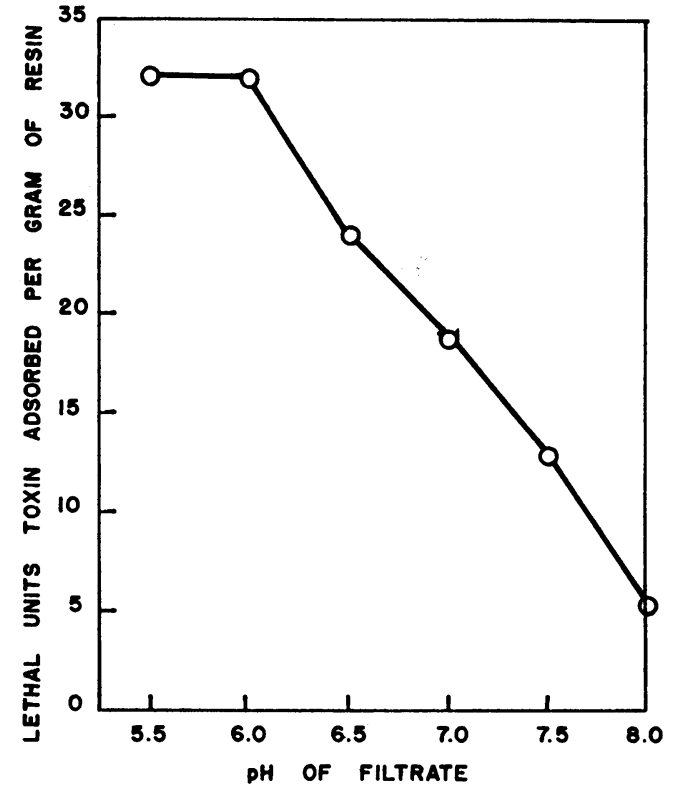

Figure 3 . The effect of $\mathrm{pH}$ on toxin adsorption from $30 \mathrm{ml}$ of toxin 11 by $4 \mathrm{~g}$ of Duolite $\mathrm{S}-30$ in $20 \mathrm{~min}$ at room temperature. The $\mathrm{pH}$ of the filtrate and of the slurry after addition of the resin was adjusted with $1 \mathrm{~N} \mathrm{HCl}$ or $\mathrm{NaOH}$. Untreated filtrate contained $5.7 \mathrm{LU} / \mathrm{ml}$.

qualitative difference between the toxin collected in fractions 50 to 90 and fractions 115 to 140 was striking. None of the fractions from 10 to 100 produced necrosis on intradermal inoculation into normal guinea pigs, but typical necrosis was 


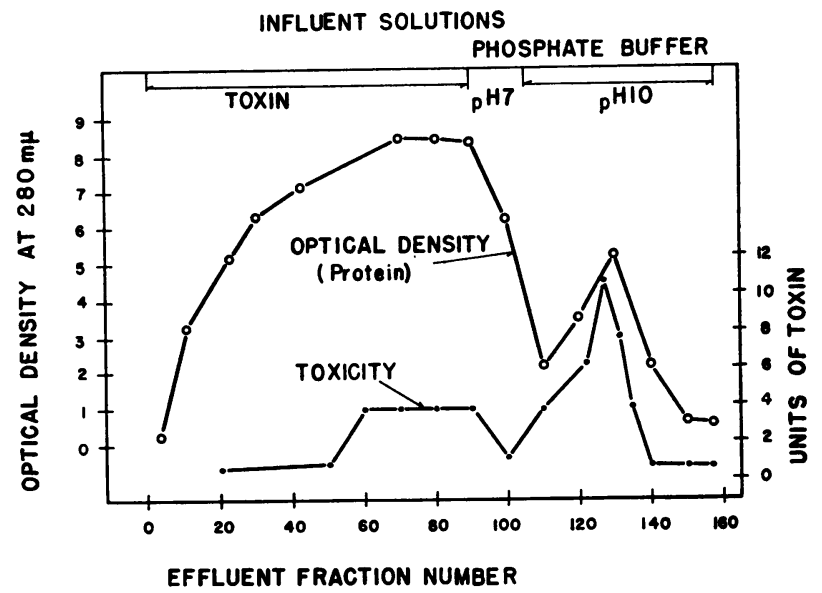

Figure 4. Adsorption of toxin from crude filtrate 51 by Duolite S-30 and elution with pH 10 buffer. Both pH 7.0 and pH 10 buffers were $0.05 \mathrm{~m}$ sodium phosphate. The resin column was approximately 15 $\mathrm{cm}$ long with a bed volume of $5 \mathrm{ml}$ and the rate of flow was $0.2 \mathrm{ml}$ per min. Four ml fractions were collected at $20 \mathrm{~min}$ intervals.

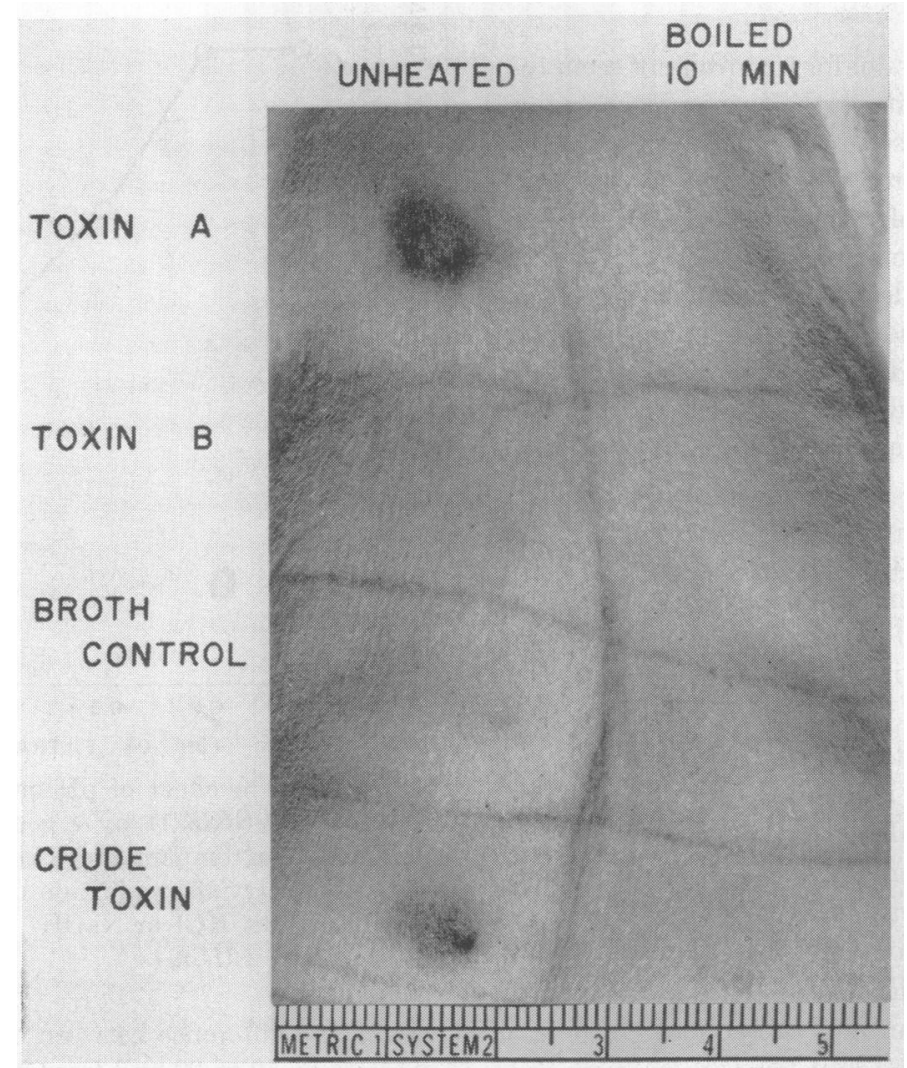

Figure 5. The effect of intradermal inoculation into a normal guinea pig of toxins separated by adsorption with Duolite S-30 (see figure 4). Toxin A was a pool of effluent fractions 120 to 140 (pH 10 eluate) and toxin B was a pool of effluent fractions 69 to 90 . The guinea pig was photographed $3 \mathrm{hr}$ after inoculation. 
produced by fractions 115 to 140 . Pools of fractions 69 to 90 and 120 to 140 , and an aliquot of the crude toxin (51-C) were all adjusted to 3.2 $\mathrm{LU} / \mathrm{ml}$ to provide material for direct comparisons. Figure 5 shows a guinea pig $3 \mathrm{hr}$ after inoculation of the various preparations. Toxin A (adsorbed by Duolite S-30 at pH 6.8 and eluted by $\mathrm{pH} 10$ buffer) was obviously necrotizing whereas toxin B was not, although both preparations were equally lethal for mice. The necrotoxin in the eluate as well as that in the crude filtrate was inactivated by boiling.

\section{DISCUSSION}

During the first two years of this study it appeared that the toxicity of culture filtrates of $P$. pseudomallei was due to a single thermolabile toxin but later work showed that at least two different toxins were implicated. Other toxins might be produced under special conditions, such as are found only in vivo.

The crude filtrates contained certain biologically active substances in addition to the toxins described above. These filtrates were, for instance, strongly proteolytic since as little as $0.002 \mathrm{ml}$ digested $5 \mathrm{mg}$ of casein in $30 \mathrm{~min}$. They also digested albumin, gelatin, skin, and hemoglobin. More than one enzyme may be involved in this proteolytic activity although it could possibly be due to a single, wide spectrum enzyme similar to trypsin. Although the initial lesion resulting from intradermal inoculation of the necrotoxin seemed to be caused by enzymatic activity, the relationship between such activity and toxicity requires further study. The production of a number of biologically active substances by $P$. pseudomallei is not unique as certain other pathogens also produce a variety of toxins or extracellular enzymes.

Liu (1957) recently confirmed the production of lethal and necrotizing toxin by $P$. pseudomallei. Although he also demonstrated hemolysin production, there was no evidence of hemolytic activity in any of the crude filtrates tested in this study, in spite of their pronounced proteolytic activity.

In dealing with biologically active materials it is of interest to speculate as to their specific activity. In view of the relatively low toxicity of the filtrates, it might seem that the exotoxins of $P$. pseudomallei are not as active as those of other organisms. However, there is some evidence which would indicate that the toxin was present in very small amounts but that it had a high specific activity. That the concentration of toxin in the original solution was low is suggested by the fact that no toxin was precipitated by 80 per cent ethanol which precipitates most proteins. The lethal toxin may not be a protein but it was immunogenic and was readily detoxified by formaldehyde or by heating at $60 \mathrm{C}$. The apparent precipitation of toxin by ammonium sulfate may be the result of adsorption of toxin by inert material in the precipitate. The results of electrophoresis certainly indicated that most of the fraction precipitated by ammonium sulfate was nontoxic. The loss of toxicity on dialysis against distilled water constitutes additional evidence that the concentration of toxin in crude filtrates was low since enzymes are often less stable in dilute than in more concentrated solutions. Or possibly such dialysis removed some protective substance which was replaceable by phosphate or organic compounds present in peptone.

In view of the stability of toxin in ethanol solutions at room temperature, it was unexpected that it should be so sensitive to other treatments. It is not unusual that a toxin or enzyme is stable only within narrow $\mathrm{pH}$ limits, or is denatured at $60 \mathrm{C}$, but it is difficult to reconcile the instability of toxin in distilled water with its stability in organic solvents.

The stability of the toxins in alcohol or acetone is evidence that they are not lipoproteins because such proteins, with loosely bound prosthetic groups, are particularly sensitive to organic solvents at temperatures above $0 \mathrm{C}$.

The reason for the inactivation of toxin on lyophilization in solutions containing glycerin has not been studied but one can postulate that the toxin was denatured by the high concentration of electrolytes and surface tension effects produced by evaporation of water since glycerin prevented freezing.

It is hoped that the more active filtrates obtained from mucin broth (Colling et al., 1958) will be more satisfactory for purification and identification of the toxins.

\section{ACKNOWLEDGMENT}

Grateful acknowledgment is made to Miss Margaret Colling for preparing most of the culture filtrates used in these studies and to $\mathrm{Mr}$. Warren A. Clark for his technical assistance.

\section{SUMMARY}

Two thermolabile exotoxins were demonstrated in crude filtrates of Pseudomonas pseudomallei by selective adsorption and elution from 
Duolite S-30 resin. One toxin was lethal and necrotizing, whereas the other toxin was lethal but nonnecrotizing. The lethal toxin was immunogenic. Neither toxin was inactivated by acetone or alcohol, but both were detoxified by phenol or formaldehyde. Both toxins were precipitated by ammonium sulfate at a final concentration of 35 per cent. The lethal toxin was most stable between $\mathrm{pH} 6$ and 9 . Both exotoxins are probably low molecular weight proteins with few ionizable radicals.

\section{REFERENCES}

Colling, M., NigG, C., ANd Heckly, R. J. 1958 Toxins of Pseudomonas pseudomallei. I. Production in vitro. J. Bacteriol., 76, 422-426. HECKLY, R. J. 1954 Electrophoretic studies of foot-and-mouth disease virus. Am. J. Vet. Research, 15, 252-254.

HECKLY, R. J. 1958 Electrolytically controlled device for dispensing liquids. Science, 127, 233-234.

Heckly, R. J., Anderson, A. W., ANd RockenMACHer, M. 1958 Lyophilization of Pasteurella pestis. Appl. Microbiol., 6, 255-261.

Heckly, R. J. and Watson, D. W. 1951 An improved ultrafiltration apparatus. Am. Rev. Tuberc., 63, 718-720.

Liv, P. V. 1957 Survey of hemolysin production among species of pseudomonads. J. Bacteriol., 74, 718-727.

Niga, C., Heckly, R. J., and Colling, M. 1955 Toxin produced by Malleomyces pseudomallei. Proc. Soc. Exptl. Biol. Med., 89, 17-20. 